\title{
Klasifikasi Penentuan Pengajuan Kartu Kredit Menggunakan K-Nearest Neighbor
}

\author{
Yogiek Indra Kurniawan ${ }^{1}$, Tiyssa Indah Barokah ${ }^{2}$ \\ Informatika, Universitas Jenderal Soedirman ${ }^{1}$, \\ Informatika, Universitas Muhammadiyah Surakarta ${ }^{2}$ \\ Jl. Prof. Dr. HR. Boenjamin 708, Purwokerto, Indonesia ${ }^{1}$, \\ Jl. A. Yani Tromol Pos I, Pabelan, Kartasura, Surakarta, Indonesia ${ }^{2}$ \\ Sur-el : yogiek@unsoed.ac.id ${ }^{1}$, indahtiyssa@gmail.com²
}

\begin{abstract}
A credit card is a device payment issued by the bank certain made of plastic and useful as a tool payment on credit carried out by the owner of the card or in accordance with the name of listed in a credit card is on when making purchases goods or services. The problems facing in giving a credit cards to customers bank that have signed up is difficult to determine the category of a credit cards in accordance with the customer bank. By doing this research is expected to facilitate the bank or the analysis to determine the category of a credit card to customers bank right. The research used is by applying methods K-Nearest Neighbor to classify prospective customers in the making a credit card in accordance with the category of customers by using data customers at the Bank BNI Syariah Surabaya. A method K-Nearest Neighbor used to seek patterns on the data customers so established variable as factors supporters in the form of gender, the status of the house, the status, the number of dependants (children), a profession and revenue annually. The results of this research shows that an average of the value of precision of $92 \%$, the value of recall of $83 \%$, and the value of accuracy of 93\%. Thus, this application is effective to help analyst credit cards in classifying customers to get credit cards that appropriate criteria.
\end{abstract}

Keywords: classification, credit card determination, data mining, K-Nearest Neighbor

\begin{abstract}
Abstrak :Kartu kredit adalah sebuah alat pembayaran yang dikeluarkan oleh bank tertentu berbahan plastik dan berguna sebagai alat pembayaran secara kredit yang dilakukan oleh pemilik kartu/sesuai dengan nama yang tertera pada kartu kredit tersebut pada saat melakukan pembelian barang atau jasa. Permasalahan yang dihadapi dalam pemberian kartu kredit kepada nasabah bank yang telah mendaftar adalah sulitnya menentukan kategori kartu kredit yang sesuai dengan nasabah bank. Dengan melakukan penelitian ini diharapkan dapat mempermudah pihak bank atau pihak analis untuk menentukan kategori kartu kredit untuk nasabah bank secara tepat. Metode penelitian yang digunakan yaitu dengan menerapkan metode K-Nearest Neighbor untuk mengklasifikasikan calon nasabah dalam pembuatan kartu kredit sesuai dengan kategori nasabah dengan menggunakan data nasabah pada Bank BNI Syariah Surabaya. Metode K-Nearest Neighbor digunakan untuk mencari pola-pola pada data nasabah sehingga di dapatkan variabel sebagai faktor pendukung berupa jenis kelamin, status rumah, status, jumlah tanggungan (anak), profesi dan penghasilan per tahun. Hasil dari penelitian ini menunjukkan bahwa rata-rata nilai precision sebesar 92\%, nilai recall sebesar 83\%, dan nilai accuracy sebesar 93\%. Dengan demikian, aplikasi ini sudah efektif untuk membantu pihak analis kartu kredit dalam pengklasifikasikan nasabah untuk mendapatkan kartu kredit yang sesuai dengan kriteria.
\end{abstract}

Kata kunci: data mining, klasifikasi, K-Nearest Neighbor, penentuan kartu kredit.

\section{PENDAHULUAN}

Kartu kredit adalah sebuah alat pembayaran yang dikeluarkan oleh bank tertentu berbahan plastik dan berguna sebagai alat pembayaran secara kredit yang dilakukan oleh pemilik kartu/sesuai dengan nama yang tertera pada kartu kredit tersebut pada saat melakukan pembelian barang atau jasa, dan juga bisa digunakan untuk menarik uang tunai secara 
mandiri di mesin ATM yang sesuai dengan batas kredit yang telah ditetapkan oleh penerbit

Bank merupakan salah satu lembaga yang berhak mengeluarkan kartu kredit sehingga tugas mereka pula menentukan jenis kartu kredit yang sesuai untuk para nasabah. Permasalahan yang dihadapi dalam pemberian kartu kredit kepada nasabah bank yang telah mendaftar adalah sulitnya menentukan kategori kartu kredit yang sesuai dengan nasabah bank.

Paper ini mengambil data studi kasus pada penelitian [1],[2] berupa kasus pengajuan kartu kredit. Pada paper [1],[2] menyelesaikan kasus pengajuan kartu kredit menggunakan metode klasifikasi yaitu Nä̈ve Bayes dan C.45 dengan hasil yang berbeda. Hal ini menunjukkan kasus kartu kredit dapat diselesaikan dengan menggunakan metode klasifikasi data mining, dikarenakan pada penentuan akhir kartu kredit, nasabah akan dimasukkan ke dalam golongan "Tidak Diterima”, "Classic", "Gold", dan "Platinum" berdasarkan beberapa kriteria maupun variabel-variabel yang ada pada nasabah tersebut.

Salah satu algoritma yang dapat digunakan untuk klasifikasi adalah $K$-Nearest Neighbor (KNN) [3]. Algoritma ini dapat digunakan untuk kasus klasifikasi, sebagaimana ditunjukkan oleh beberapa penelitian sebelumnya. Metode K-Nearest Neighbor dapat digunakan untuk memberikan informasi tentang klasifikasi calon penerima beasiswa Peningkatan Prestasi Akademik (PPA) dan Bantuan Belajar Mahasiswa (BBM) [4]. Sebuah sistem pendukung keputusan menggunakan metode $K$ Nearest Neighbor juga dapat di implementasikan ke dalam seleksi penerimaan peserta paskibraka pada Dinas Pemuda dan Olahraga Provinsi Bengkulu[5]. Beberapa penelitian sebelumnya, seperti pada paper $[6,7,8]$ juga menunjukkan bahwa K-Nearest Neighbor dapat digunakan untuk klasifikasi berbagai macam kasus. Selain itu, K-Nearest Neighbor merupakan salah satu metode yang dapat digunakan untuk klasifikasi data mining dengan hasil yang menjanjikan sebagaimana ditunjukkan oleh penelitianpenelitian sebelumnya[9, 10, 11]. K-Nearest Neighbor (K-NN) adalah sebuah metode untuk melakukan klasifikasi terhadap objek berdasarkan data pembelajaran yang jaraknya paling dekat dengan objek tersebut. Hal ini memudahkan dalam pencarian klasifikasi atau penentuan prediksi dari sebuah variabel.

Dengan adanya kesulitan menentukan kategori kartu kredit yang sesuai dengan nasabah bank maka dipilih metode K-Nearest Neighbor dan telah banyak digunakan dalam penelitian ataupun dalam suatu studi kasus. Metode $K$ Nearest Neighbor digunakan untuk menyelediki dan meninjau estimasi tentang apakah pembayaran kartu kredit pada bulan selanjutnya akan dilakukan oleh nasabah atau tidak dan klasifikasi tersebut menggunakan aplikasi persetujuan kartu kredit dengan menunjukkan tingkat klasifikasi KNN dengan memvariasikan nilai $\mathrm{k}[12]$.

Penelitian [13] membuktikan algoritma $K$ Nearest Neighbor dapat dipergunakan untuk memprediksi kelayakan calon anggota kredit yang merupakan salah satu kasus klasifikasi. Sedangkan, Penelitian [14] mencoba menerapkan beberapa metode data mining pada 
sebuah studi kasus pembayaran kartu kredit. Penelitian tersebut membuktikan bahwa $K$ Nearest Neighbor dapat diterapkan pada kasus kartu kredit yang memberikan hasil cukup menjanjikan.

Berdasarkan kesimpulan-kesimpulan pada berbagai penelitian tersebut maka pada paper ini dilakukan implementasi metode $K$-Nearest Neighbor untuk membuat aplikasi klasifikasi penentuan pengajuan kartu kredit di Bank BNI Syariah Surabaya. Dengan mencari pola-pola pada data nasabah yang ada pada Bank BNI Syariah Surabaya tersebut di dapatkan variabel sebagai faktor pendukung berupa jenis kelamin, status rumah, status, jumlah tanggungan (anak), profesi dan penghasilan per tahun serta variabel akhir adalah klasifikasi kartu kredit.

Penelitian ini bertujuan agar dapat menghasilkan suatu aplikasi berbasis web dengan mengklasifikasikan data nasabah menggunakan metode K-Nearest Neighbor agar penentuan dari pihak bank atau pihak penerbit kartu kredit bisa sesuai dengan kriteria nasabah yang mengajukan pembuatan kartu kredit. Setelah itu, dilakukan pengujian terhadap algoritma menggunakan pengujian blackbox, pengujian algoritma serta pengujian precision, recall dan accuracy untuk mengevaluasi penggunaan algoritma $K$-Nearest Neighbor.

\section{METODE PENELITIAN}

Metode penelitian yang digunakan dalam penelitian ini mengacu pada Gambar 1. Setiap langkah memiliki kegiatan masing-masing.

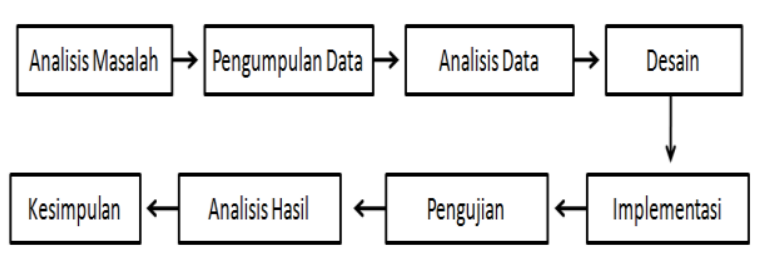

\section{Gambar 1. Metode Penelitian}

\subsection{Analisis Masalah}

Pada tahapan analisis masalah digunakan untuk mengetahui permasalahan-permasalahan yang terjadi pada penelitian ini, khususnya pada bank BNI Syariah Surabaya yang memerlukan suatu sistem aplikasi klasifikasi penentuan pengajuan kartu kredit untuk nasabah yang mengajukan pembuatan kartu kredit sehingga memudahkan pihak penerbit kartu kredit atau pihak bank tersebut.

\subsection{Pengumpulan Data}

Pada tahapan pengumpulan data didapatkan dengan jumlah 250 data penelitian berupa data nasabah di Bank BNI Syariah Surabaya, dengan jumlah 250 data yang dipakai sebagai data training, sedangkan untuk data testing diambil sampel dari data training yang di dapat sebelumnya dengan jumlah data testing 100 data. Data diambil dari penelitian [1][2].

\subsection{Analisis Data}

Pada tahapan analisis data ini setelah didapatkan data kemudian dianalisis guna menentukan variabel-variabel pada data nasabah yang mengajukan pembuatan kartu kredit, kemudian akan di terapkan kedalam aplikasi. Variabel-variabel yang dibutuhkan dalam penelitian ditunjukkan seperti Tabel 1.

Tabel 1. Variabel Penelitian 


\begin{tabular}{|c|c|c|}
\hline Variabel & Tipe & Isi \\
\hline $\begin{array}{l}\mathrm{X} 1: \text { Jenis } \\
\text { Kelamin }\end{array}$ & Binomial & Laki-laki, Perempuan \\
\hline $\begin{array}{l}\mathrm{X} 2: \text { Status } \\
\text { Rumah }\end{array}$ & Polynomial & $\begin{array}{l}\text { Milik Sendiri, Milik } \\
\text { Keluarga, dan Sewa. }\end{array}$ \\
\hline $\mathrm{X} 3$ : Status & Binomial & $\begin{array}{l}\text { Belum Kawin dan } \\
\text { Kawin. }\end{array}$ \\
\hline $\begin{array}{l}\text { X4 : Jumah } \\
\text { Tanggungan }\end{array}$ & Polynomial & $\begin{array}{l}0,0 \leq \text { anak, dan anak } \\
>2 .\end{array}$ \\
\hline X5 : Profesi & Polynomial & $\begin{array}{l}\text { PNS, BUMN, dan } \\
\text { Swasta. }\end{array}$ \\
\hline $\begin{array}{l}\text { X6 : } \\
\text { Penghasilan / } \\
\text { tahun }\end{array}$ & Polynomial & $\begin{array}{l}\text { Rendah, Sedang, } \\
\text { Tinggi, dan Sangat } \\
\text { Tinggi. }\end{array}$ \\
\hline $\begin{array}{l}\text { Y : Kartu } \\
\text { Kredit }\end{array}$ & Label & $\begin{array}{l}\text { Tidak Diterima, } \\
\text { Classic, Gold, dan } \\
\text { Platinum. }\end{array}$ \\
\hline
\end{tabular}

\subsection{Desain Aplikasi}

Tahap desain ini bertujuan menjelaskan bagaimana proses dalam aplikasi yang akan dibuat menggunakan K-Nearest Neighbor. Dalam proses desain terdapat Use case dari aplikasi yang di rancang dengan menggunakan Gambar 2.

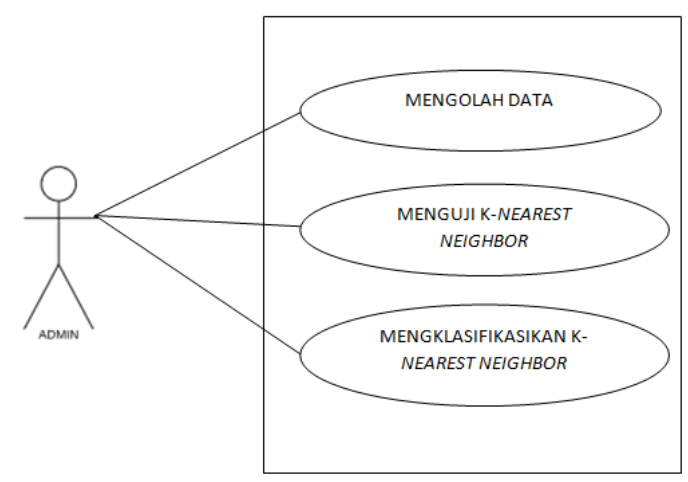

\section{Gambar 2. Use Case Aplikasi}

1) Mengolah Data : Pada tahap desain terdapat pengolahan data dengan cara admin memasukkan data training satu per-satu ke dalam aplikasi atau dengan cara mengunggah file yang berisi data training yang berektensi excel untuk data-data yang berkapasitas besar. Admin juga dapat melakukan update dan delete data yang salah.

2) Menguji K-Nearest Neighbor : Pada tahap desain juga dilakukan pengujian $K$-Nearest Neighbor yang bertujuan guna melakukan perhitungan untuk mendapatkan keakuratan hasil dari sistem, dengan memasukkan beberapa data sebagai data testing yang di dapat dari data training. Alur yang digunakan adalah dengan memasukkan berbagai data dalam perhitungan sehingga didapatkan parameter $\mathrm{k}$ (jumlah tetangga terdekat), menghitung kuadrat jarak eucliden pada data training, mengurutkan hasil dari kuadrat jarak eucliden secara ascending, menentukan variabel $\mathrm{Y}$ berdasarkan nilai pada $\mathrm{k}$, menentukan probabilitas tertinggi sehingga dapat dihitung precision, recall, dan accuracy pada aplikasi tersebut.

3) Klasifikasi K-Nearest Neighbor : Pada Tahap terakhir desain, didapat bahwa dalam aplikasi tersebut dengan mengklasifikasikan $K$-Nearest Neighbor akan didapatkan hasil klasifikasi berupa jenis kartu kredit yang sesuai dengan nasabah yang mengajukan pembuatan kartu kredit.

\subsection{Implementasi Aplikasi}

Pada tahap ini aplikasi mulai di bangun mengunakan bahasa pemrograman PHP (Hypertext Prepocessor) dengan desain yang telah dibuat, aplikasi ini berbasis web dan editornya memakai Sublime Text 3, sedangkan untuk penyimpanan database menggunakan MySQL dengan metode K-Nearest Neighbor. 
Algoritma K-Nearest Neighbor merupakan salah satu metode klasifikasi pengambilan keputusan berdasarkan jarak terdekat pada data nilai[5] dengan persamaan yang digunakan matriks satuan jarak atau biasanya menggunakan Eucliden :

$$
\mathrm{D}\left(\mathrm{x}_{1}, \mathrm{x}_{2}\right)=\sqrt{\sum_{\mathrm{i}=1}^{\mathrm{n}}(\mathrm{x} 1-\mathrm{x} 2)^{2}}
$$

Keterangan :

D : jarak terdekat

X1: Sampel data atau Data Training

X2: Data uji atau Data Testing

$\mathrm{n}$ : Jumlah atribut setiap kasus

i : Atribut individu dari 1 sampai $n$

Perhitungan klasifikasi nasabah yang melakukan pengajuan kartu kredit dapat dihitung dengan menggunakan metode $K$-Nearest Neighbor dengan langkah-langkah sebagai berikut :

1. Menghitung jarak eucliden pada data training.

2. Mengurutkan hasil dari jarak eucliden secara asceding (berurutan dari kecil ke besar).

3. Menentukan parameter k (jumlah tetangga terdekat). Penentuan parameter $\mathrm{k}$ (jumlah tetangga terdekat) pada penelitian ini menggunakan $\mathrm{k}=5$. Nilai $\mathrm{k}$ yang digunakan dalam penelitian ini seluruhnya menggunakan nilai ganjil karena label/hasil akhir klasifikasi mempunyai 4 kemungkinan yaitu classic, gold, platinum dan tidak diterima, sehingga $\mathrm{k}=5$ merupakan parameter terdekat dari hasil akhir.

4. Menentukan variabel $\mathrm{Y}$ atau pada kategori kartu kredit berdasarkan pada nilai $\mathrm{k}$.

5. Menentukan probabilitas tertinggi.
Pengujian diperlukan untuk mengevaluasi sebuah perangkat lunak baik dari sisi fungsionalitas maupun kinerja dari perangkat lunak tersebut[15]. Pengujian dilakukan dengan 3 tahap, yaitu pengujian blackbox untuk menguji fungsionalitas sistem yang dibangun, pengujian algoritma untuk mengetahui apakah algoritma di dalam sistem sudah berhasil diimplementasikan serta pengujian precision, recall, dan accuracy untuk mengukur performa dari algoritma.

Setelah melakukan proses klasifikasi dengan metode K-Nearest Neighbor, maka selanjutnya mengukur kinerja dari hasil klasifikasi dengan menghitung precision, recall, dan accuracy. Berdasarkan [16], precision, recall, dan accuracy dapat didefinisikan sebagai berikut :

Precision adalah ketepatan dari kasus positif yang diprediksi secara benar. Nilai Precision dapat dihitung dengan persamaan :

$$
\text { Precision }=\frac{\mathrm{TP}}{(\mathrm{TP}+\mathrm{FP})}
$$

Recall adalah ketepatan dari kasus positif yang diidentifikasi secara benar dan dihitung dengan persamaan :

$$
\text { Recall }=\frac{\mathrm{TP}}{(\mathrm{TP}+\mathrm{TN})}
$$

Accuracy adalah ketepatan dari jumlah data yang diprediksi secara benar dan dihitung dengan persamaan :

$$
\text { Accuracy }=\frac{\mathrm{TP}+\mathrm{TN}}{\mathrm{TP}+\mathrm{FN}+\mathrm{FP}+\mathrm{TN}}
$$

Keterangan :

$\mathrm{TP}($ True Positives $)=$ Jumlah objek positif yang benar diklasifikasikan.

$\mathrm{TN}($ True Negatives $)=$ Jumlah objek negatif yang salah diklasifikasikan.

\subsection{Pengujian}


$\mathrm{FP}($ False Positives $)=$ Jumlah objek negatif yang benar diklasifikasikan.

$\mathrm{FN}$ (False Negatives) = Jumlah objek positif yang salah diklasifikasikan.

\subsection{Analisa Hasil}

Pada tahap analisa hasil ini dilakukan perbandingan antara hasil perhitungan manual dengan hasil perhitungan menggunakan aplikasi yang dibuat menggunakan metode K-Nearest Neighbor beserta dengan presentase kesalahan dari aplikasi yang telah dibangun.

\subsection{Kesimpulan}

Pada tahap kesimpulan ini dapat disimpulkan bahwa hasil dari semua proses yang dilakukan guna membangun sebuah aplikasi yang bisa bermanfaat dalam penelitian ini.

\section{HASIL DAN PEMBAHASAN}

\subsection{Hasil Penelitian}

Implementasi aplikasi merupakan tahapan penerapan atau pelaksanaan dari desain/rancangan yang telah dibuat sebelumnya, sehingga bisa untuk mengetahui hasil rancangan tersebut. Hasil yang didapatkan dari penelitian ini adalah sebuah aplikasi penentuan pengajuan kartu kredit menggunakan metode K-Nearest Neighbor di Bank BNI Syariah Surabaya.

Aplikasi yang telah dibuat terdapat beberapa menu yaitu Home, menu Data Training, menu Data Testing, menu Pengujian yang akan di akses oleh analisis kartu kredit sebagai administrator, menu Prediksi yang akan memprediksi data yang secara langsung telah di inputkan oleh admin. Untuk mengakses aplikasi ini admin diwajibkan untuk login terlebih dahulu dengan memasukkan username dan password.

\section{a) Halaman Utama}

Halaman utama dari aplikasi ini adalah halaman pada form login, dengan pemberian hak akses oleh administrator maka admin harus login terlebih dahulu dengan memasukkan username dan password sesuai dengan database.

\section{b) Halaman Home}

Halaman Home akan muncul ketika admin telah berhasil login. Pada halaman ini berisi informasi singkat tentang aplikasi ini dan terdapat menu-menu lain seperti Data Training, Data Testing, Pengujian, Logout dengan fungsi yang berbeda-beda.

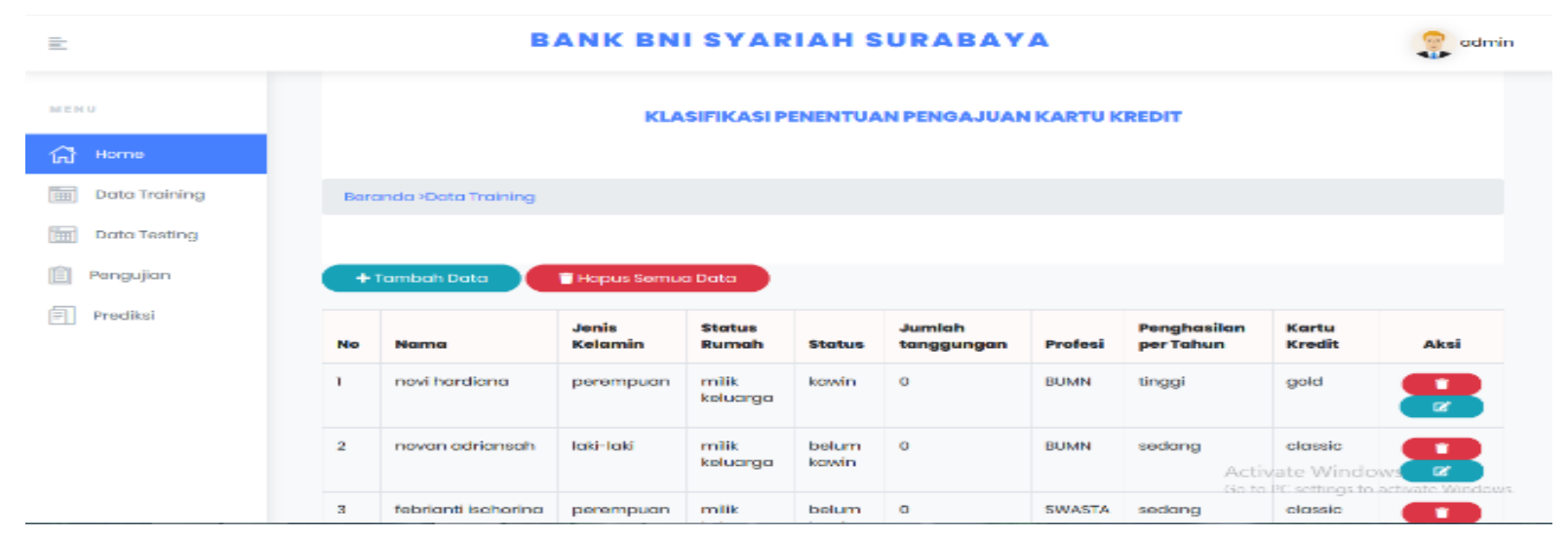

Gambar 3. Halaman Data Training 


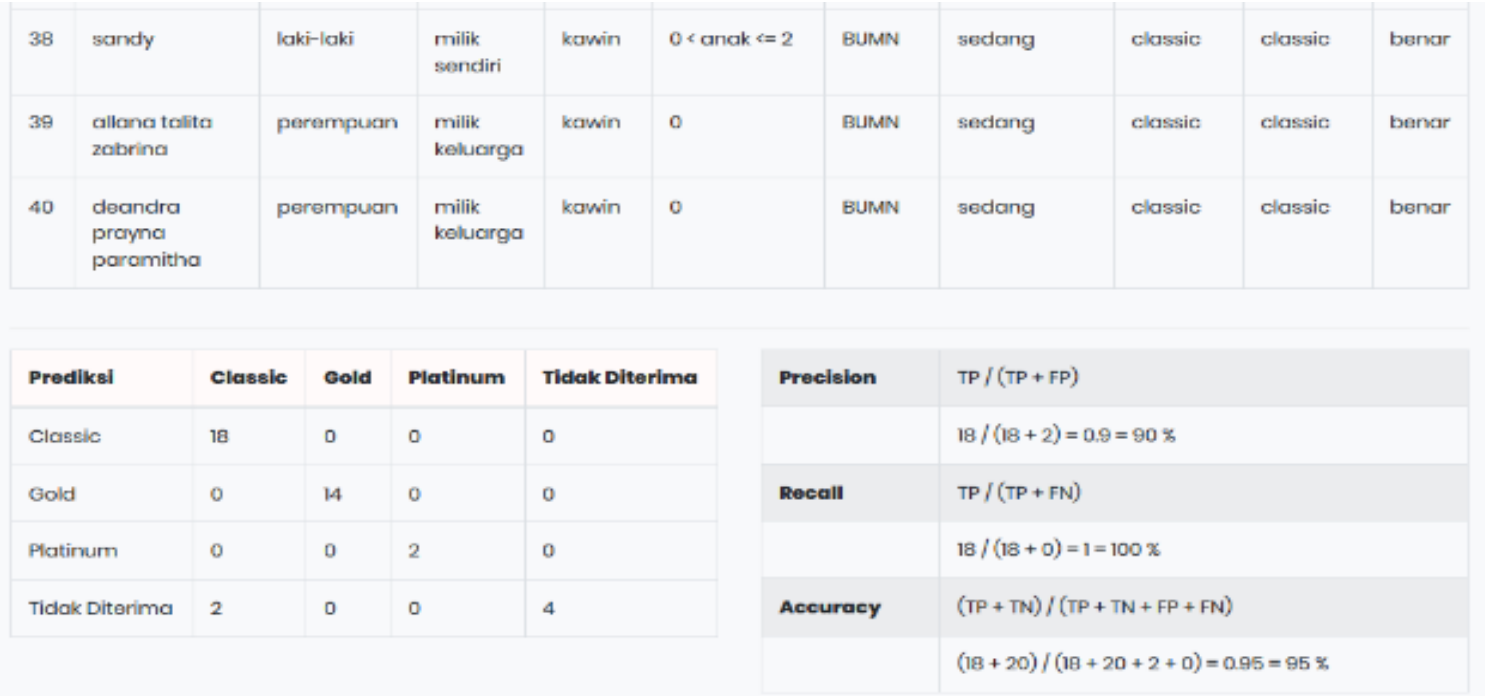

Gambar 4. Halaman Pengujian

\section{c) Halaman Data Training}

Halaman data training berfungsi untuk menampilkan daftar data training dari nasabah yang telah diinputkan. Pada menu data training terdapat tombol-tombol seperti tambah data untuk menambahkan data training nasabah satupersatu atau dengan cara import dari file excel dengan format *.xls. Setelah diinputkan data tersebut dapat di edit dan di hapus jika admin salah memasukkan data atau jika ingin menghapus keseluruhan data maka terdapat tombol hapus semua data. Halaman data training ditujukkan pada Gambar 3.

\section{d) Halaman Data Testing}

Halaman data testing berfungsi untuk menampilkan data testing nasabah yang telah diinputkan. Pada menu data testing terdapat tombol-tombol seperti tambah data untuk menambahkan data testing nasabah satu-persatu atau dengan cara import dari file excel dengan format *.xls. Setelah diinputkan data tersebut dapat di edit dan di hapus jika admin salah memasukkan data atau jika ingin menghapus keseluruhan data maka terdapat tombol hapus semua data. Halaman Data Testing memiliki tampilan yang sama dengan Halaman Data Training di gambar 3.

\section{d) Halaman Pengujian}

Halaman pengujian berfungsi untuk menampilkan data testing dengan disertai prediksi kartu kredit dari perhitungan sistem beserta hasilnya. Pada kolom hasil akan muncul kata "benar" dan kata "tidak benar" untuk mencocokan perbandingan dengan kolom prediksi. Halaman pengujian ditunjukkan pada Gambar 4.

\subsection{PEMBAHASAN}

Pada bagian ini akan dijelaskan mengenai pengujian terhadap aplikasi yang telah dibangun serta analisis terhadap hasil pengujian yang telah dilakukan.

\section{a) Pengujian Blackbox}

Pengujian blackbox berfungsi untuk mengamati hasil eksekusi aplikasi tersebut dan memeriksa fungsionalitas dari aplikasi yang 
dibuat. Pengujian blackbox juga digunakan untuk menguji fitur dan fungsionalitas dari sebuah perangkat lunak[17]. Pengujian ini digunakan untuk mencari kesalahan yang ada didalam aplikasi sehingga dapat dilakukan perbaikan aplikasinya sehingga menjamin kualitas aplikasi. Hasil pengujian blackbox ditunjukkan pada Tabel 2.

Dari hasil pengujian Blackbox, dapat disimpulkan bahwa setiap menu/fitur yang ada telah sesuai dengan fungsionalitasnya dan Valid.

\section{b) Pengujian Algoritma}

Pengujian algoritma K-Nearest Neighbor telah diuji dengan memasukkan 5 data training dan 1 data testing, kemudian membandingkan antara perhitungan sistem dan perhitungan manual pada bagian implementasi diatas. Maka didapatkan hasil bahwa klasifikasi yang dilakukan antara keduanya adalah sama. Sehingga membuktikan bahwa aplikasi yang di bangun dengan menerapkan algoritma $K$-Nearest Neighbor adalah benar.

\section{c) Pengujian Precision, Recall, dan Accuracy}

Pengujian Precision, Recall, dan Accuracy dilakukan dengan memasukkan setiap data training yang meningkat dengan kelipatan 50 data. Setiap data training diambil secara acak dari keseluruhan data. Data training tersebut diuji dengan sebuah data testing yang berisi 100 data. Setiap pengujian dilakukan sebanyak 3 kali dan diambil nilai rata-rata dari setiap pengujian. Hasil perhitungan rata-rata precision, recall, dan accuracy dari 3 kali percobaan dapat ditunjukkan pada gambar 5.

Tabel 2. Hasil Pengujian Blackbox

\begin{tabular}{|c|c|c|c|c|}
\hline No & Menu & Test Case & Harapan & Hasil \\
\hline 1 & Login & $\begin{array}{l}\text { Masuk ke aplikasi dengan } \\
\text { memasukkan username dan } \\
\text { password yang sesuai }\end{array}$ & Masuk ke halaman Home & Valid \\
\hline 2 & Logout & Klik tombol logout & Keluar dari aplikasi & Valid \\
\hline 3 & Home & Klik menu Home & Menampilkan halaman home & Valid \\
\hline 4 & $\begin{array}{l}\text { Data Training dan } \\
\text { Data Testing }\end{array}$ & $\begin{array}{l}\text { Klik menu Data Training dan Data } \\
\text { Testing }\end{array}$ & $\begin{array}{l}\text { Menampilkan data training dan data } \\
\text { testing }\end{array}$ & Valid \\
\hline 5 & $\begin{array}{l}\text { Data Training dan } \\
\text { Data Testing }\end{array}$ & Klik tambah dan edit data & $\begin{array}{l}\text { Menambahkan dan mengubah data } \\
\text { training/data testing. }\end{array}$ & Valid \\
\hline 6 & Pengujian & Klik menu pengujian & $\begin{array}{l}\text { Menampilkan hasil pengujian serta nilai } \\
\text { precision, recall, dan accuracy }\end{array}$ & Valid \\
\hline
\end{tabular}

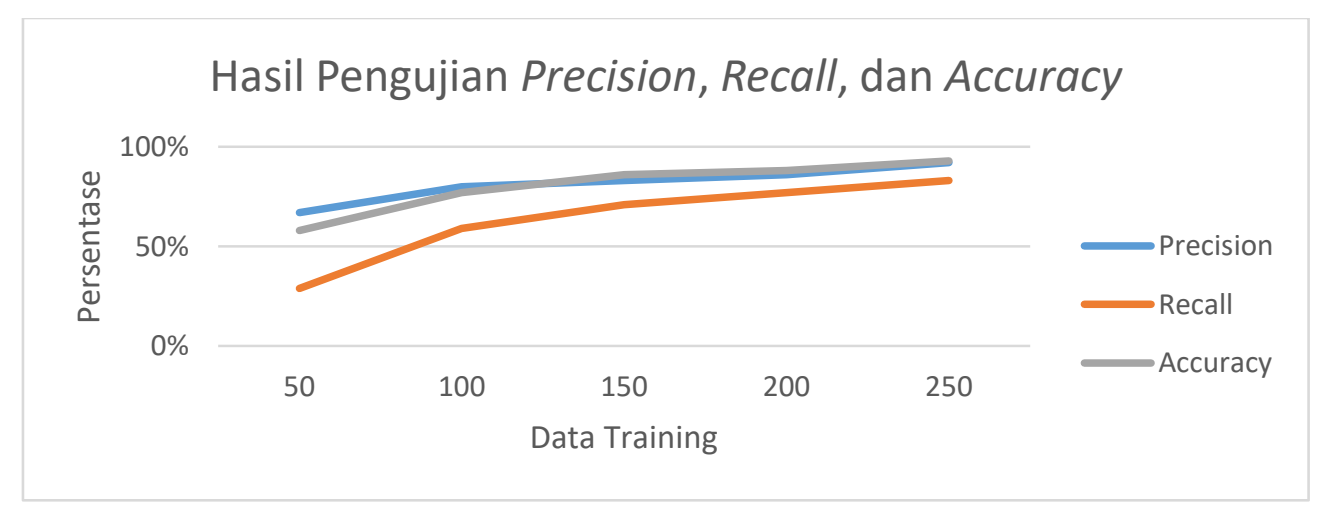

Gambar 5. Hasil Pengujian Precision, Recall, dan Accuracy 
Nilai rata-rata maksimal untuk precision adalah 92\%, sedangkan untuk recall sebesar $83 \%$ dan untuk accuracy sebesar 93\%. Dari pengujian yang dilakukan sebanyak 5 kali data uji maka dapat disimpulkan bahwa hasil Precision, Recall, dan Accuracy cenderung meningkat untuk setiap penambahan data training.

\section{d) Analisa Hasil}

Aplikasi klasifikasi penentuan pengajuan kartu kredit menggunakan metode $K$-Nearest Neighbor memiliki satu administrator sebagai aktor, administrator ini merupakan analis kartu kredit. Admin mempunyai hak akses untuk mengelola aplikasi berupa input, update, dan delete data training, data testing, melakukan pengujian dan melakukan prediksi. Pengujian dibagi menjadi 3 cara pengujian, yaitu dengan pengujian blackbox, pengujian algoritma $K$ Nearest Neighbor, dan pengujian precision, recall, dan accuracy. Pengujian blackbox bertujuan untuk mengetahui hasil eksekusi aplikasi tersebut dan memeriksa fungsionalitas dari aplikasi yang dibuat, pengujian algoritma $K$ Nearest Neighbor bertujuan untuk membuktikan bahwa aplikasi yang telah dibuat dengan algoritma K-Nearest Neighbor adalah benar dan sesuai dengan perhitungan manual, pengujian precision, recall, dan accuracy bertujuan untuk mengetahui hasil nilai perhitungan dari precision, recall, dan accuracy dengan memasukkan data training dan data testing dengan jumlah yang berbeda. Sedangkan pada prediksi dapat dilakukan dengan memasukkan data nama, jenis kelamin, status rumah, status, jumlah tanggungan, profesi, dan penghasilan per-tahun.

Hasil perhitungan aplikasi dari pengujian precision, recall, dan accuracy didapatkan nilai yang semakin meningkat dengan penambahan pada data training, rata-rata maksimal dari nilai precision sebesar $92 \%$, nilai recall sebesar $83 \%$, dan nilai accuracy sebesar 93\%. Hal ini dikarenakan dengan penambahan data training, maka nilai probabilitas pembanding untuk setiap data testing akan semakin meningkat, sehingga kemungkinan nilai yang didapat pada hasil di data testing pun akan meningkat. Peningkatan kemungkian nilai yang didapat tersebut akan meningkatkan nilai Precision, recall dan accuracy dari algoritma $K$-Nearest Neighbor.

\section{KESIMPULAN}

Berdasarkan hasil penelitian dapat disimpulkan bahwa Metode K-Nearest Neighbor dapat digunakan untuk mengklasifikasikan penentuan pengajuan kartu kredit. Setiap fitur atau menu pada aplikasi yang dibangun telah sesuai dengan rancangan yang telah didesain yang dapat dibuktikan dengan hasil pengujian Blackbox untuk memeriksa fungsionalitas dari aplikasi bernilai valid. Pengujian menggunakan metode algoritma K-Nearest Neighbor membuktikan bahwa aplikasi yang telah dibuat adalah benar dan sesuai dengan perhitungan manual. Sedangkan berdasarkan pengujian 3 kali pada data training dan data testing, didapatkan hasil rata-rata maksimal dari nilai precision sebesar 92\%, nilai recall sebesar 83\%, dan nilai accuracy sebesar 93\%. Dengan 
pertambahan data training maka nilai yang dihasilkan oleh precision, recall, accuracy cenderung meningkat.

\section{DAFTAR PUSTAKA}

[1] M. Antaristi and Y. I. Kurniawan, "Aplikasi Klasifikasi Penentuan Pengajuan Kartu Kredit Menggunakan Metode Naive Bayes di Bank BNI Syariah Surabaya," J. Tek. Elektro, vol. 9, no. 2, pp. 45-52, 2017.

[2] Y. I. Kurniawan, "Perbandingan Algoritma Naive Bayes dan C.45 Dalam Klasifikasi Data Mining," Jurnal Teknologi Informasi dan Ilmu Komputer, vol. 5, no. 4, pp. 455463, 2018.

[3] A. Zainuddin, "Implementasi K-Nearest Neighbor Untuk Klasifikasi Penduduk Miskin Di Desa Ngemplak Kidul Kabupaten Pati Jawa Tengah," J. Inform. SIMANTIK, vol. 4, no. 1, pp. 21-28, 2019.

[4] S. Sumarlin, "Implementasi Algoritma KNearest Neighbor Sebagai Pendukung Keputusan Klasifikasi Penerima Beasiswa PPA dan BBM," J. Sist. Inf. Bisnis, vol. 5, no. 1, pp. 52-62, 2015.

[5] D. Yanosma, A. J. T, and K. Anggriani, "Implementasi Metode K-Nearest Neighbor (KNN) dan Simple Addittive Weighting (SAW) dalam Pengambilan Keputusan Seleksi Anggota PASKIBRAKA (Studi Kasus: Dinas Pemuda dan Olahraga Provinsi Bengkulu)," Rekursif J. Inform., vol. 4, no. 2, pp. 222-235, 2016.

[6] Y. Guo, S. Han, Y. Li, C. Zhang, and Y. Bai, "K-Nearest Neighbor combined with guided filter for hyperspectral image classification," in International COnference On Identification, Information and Knowledge in the Internet of Things, 2018, pp. 159-165.

[7] X. Wu, J. Yang, and S. Wang, "Tea category identification based on optimal wavelet entropy and weighted k-Nearest Neighbors algorithm," Multimed. Tools Appl., vol. 77, no. 3, pp. 3745-3759, 2018.

[8] T. M. Tran, X. M. T. Le, H. T. Nguyen, and V. N. Huynh, "A novel non-parametric method for time series classification based on k-Nearest Neighbors and Dynamic Time Warping Barycenter Averaging," Eng. Appl.
Artif. Intell., vol. 78, no. October 2017, pp. 173-185, 2019.

[9] K. Mittal, G. Aggarwal, and P. Mahajan, "Performance study of K-nearest neighbor classifier and K-means clustering for predicting the diagnostic accuracy." International Journal of Information Technology, vol. 11, no. 3, pp. 535-540, 2019.

[10] A. Tekin, M. Ulas, and F. Uzun, "Analysis of the Neonatal Sepsis Data Set with Data Mining Methods". In 2019 1st International Informatics and Software Engineering Conference (UBMYK), 2019, pp. 1-4.

[11] R. Saxena, A. Johri, V. Deep, and P. Sharma, "Heart Diseases Prediction System Using CHC-TSS Evolutionary, KNN, and Decision Tree Classification Algorithm." In Emerging Technologies in Data Mining and Information Security, pp. 809-819. Springer, Singapore, 2019.

[12] M. KOKLU and K. Sabanci, "Estimation of Credit Card Customers Payment Status by Using kNN and MLP," Int. J. Intell. Syst. Appl. Eng., vol. 4, no. Special Issue-1, pp. 249-251, 2016.

[13] Y.I. Kurniawan, and F. Angguntina. "Aplikasi Prediksi Kelayakan Calon Anggota Kredit Pada KSPPS BMT Arta Jiwa Mandiri Wonogiri Menggunakan Algoritma K-Nearest Neighbor." JISKA (Jurnal Informatika Sunan Kalijaga), vol. 3, no. 2, pp. 84-94, 2019.

[14] A. Subasi, and S. Cankurt. "Prediction of default payment of credit card clients using Data Mining Techniques." In 2019 International Engineering Conference (IEC), IEEE, 2019, pp. 115-120.

[15] Y. I. Kurniawan, E. Soviana, and I. Yuliana, "Merging Pearson Correlation and TANELR algorithm in recommender system," AIP Conf. Proc., vol. 1977, 2018.

[16] P. Asthana, "A comparison of machine learning techniques for customer churn prediction," Int. J. Pure Appl. Math., vol. 119, no. 10, pp. 1-9, 2018.

[17] J. Ahmad, A. ul Hasan, T. Naqvi, and T. Mubeen, "A Review on Software Testing and Its Methodology," Manag. J. Softw. Eng., vol. 3, no. 1, 2019. 